\title{
Energy Balance of a Low Energy House with Building Structures with Active Heat Transfer Control
}

\author{
Daniel Kalús', Zuzana Straková1*, Matej Kubica \\ 1 Department of Building Services, Faculty of Civil Engineering, Slovak University of Technology in Bratislava, 81005 Bratislava, \\ Radlinského 11, Slovakia \\ * Corresponding author, e-mail: zuzana.strakova@stuba.sk
}

Received: 06 November 2020, Accepted: 02 June 2021, Published online: 14 July 2021

\begin{abstract}
A qualitatively new dimension has been introduced to the issue of building structures for energy-efficient buildings by the system of Active Thermal Insulation (ATI), which is already applied in the construction of such buildings. ATI are embedded pipe systems in the envelope structures of buildings, into which we supply a heat-carrying medium with adjusted temperature, so this constitutes a combined building-energy system. This introduces the concept of an internal energy source understood as an energy system integrated into the zone between the static part and the thermal insulation part of the building structure envelope. Under certain conditions, the ATI can serve as a heat recuperator or as an energy collector for a heat pump application. ATI consists of pipe systems embedded in building structures, in which the medium circulates heated by energy from any heat source. The function of the system is to reduce or eliminate heat losses through non-transparent structures in the winter and at the same time to reduce or eliminate heat gains in the summer. It is especially recommended to apply heat sources using renewable energy sources due to the required low temperatures of the heating medium and thus shorten the heating period in the building. Also recommended is to apply ATI for the use of waste heat. Buildings with a given system show low energy consumption and therefore meet the requirements of Directive no. 2018/844/EU, according to which, from 01.01.2021, all new buildings for housing and civic amenities should have energy needs close to zero.
\end{abstract}

Keywords

building structures with internal energy source, active thermal protection, low energy house, Active Thermal Insulation (ATI)

\section{Introduction}

Each building is unique in its own way, so in order to find all the possibilities of energy savings, it is necessary to solve each one separately. Building owners (investors) may also have different plans for construction of new buildings, or renovation of a building, respectively, associated with various requirements for gains from implementation of energy saving measures (return on investment time). Therefore, it is necessary not only to find options, but also to consider the economic consequences of the project before we spend more time solving the details. The economic efficiency of building operation is closely related to the choice of heat source/fuel base and the heating system. The environmental load is assessed using primary energy and $\mathrm{CO}_{2}$ emissions [1-3]. This paper focuses on the energy analysis of a detached family house.
The energy balance of a family house we present on the project of a demonstration low-energy house in the vicinity of Bratislava on an alternative with and without Active Thermal Insulation. The house has two floors with a flat roof.

The building is designed with natural ventilation.

\section{Architectural - disposition solution of a low energy family house}

The model house is detached two-storey building with external dimensions of $12.0 \times 8.17 \mathrm{~m}$ (Figs. 1-4 [4]).

The ground floor consists of an entrance hall, toilet, utility room, study, pantry, kitchen directly connected to the dining area and living room, from which there is access to the terrace. Further, there is a hall with a staircase with access to the $1^{\text {st }}$ floor, there are two rooms, bedroom with a wardrobe, bathroom and a toilet combined with a shower. 


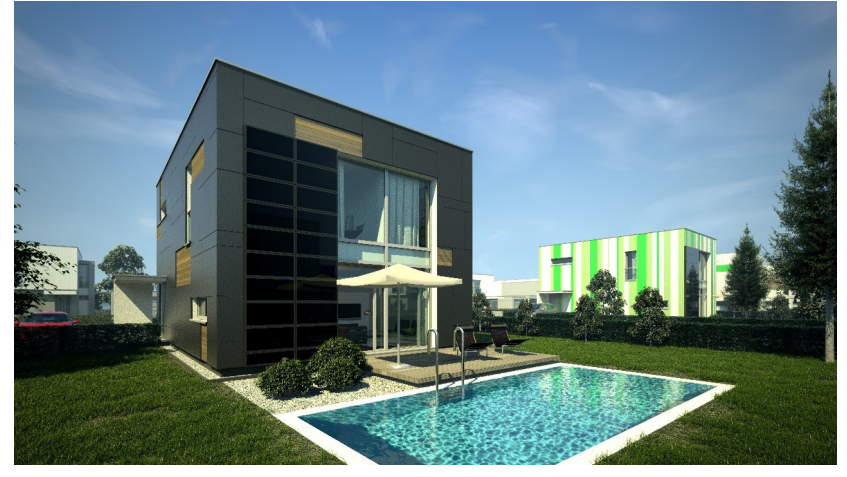

Fig. 1 Visualization of a model house (Source: architects of the building: Peter Beňuška and Peter Topinka) [4]

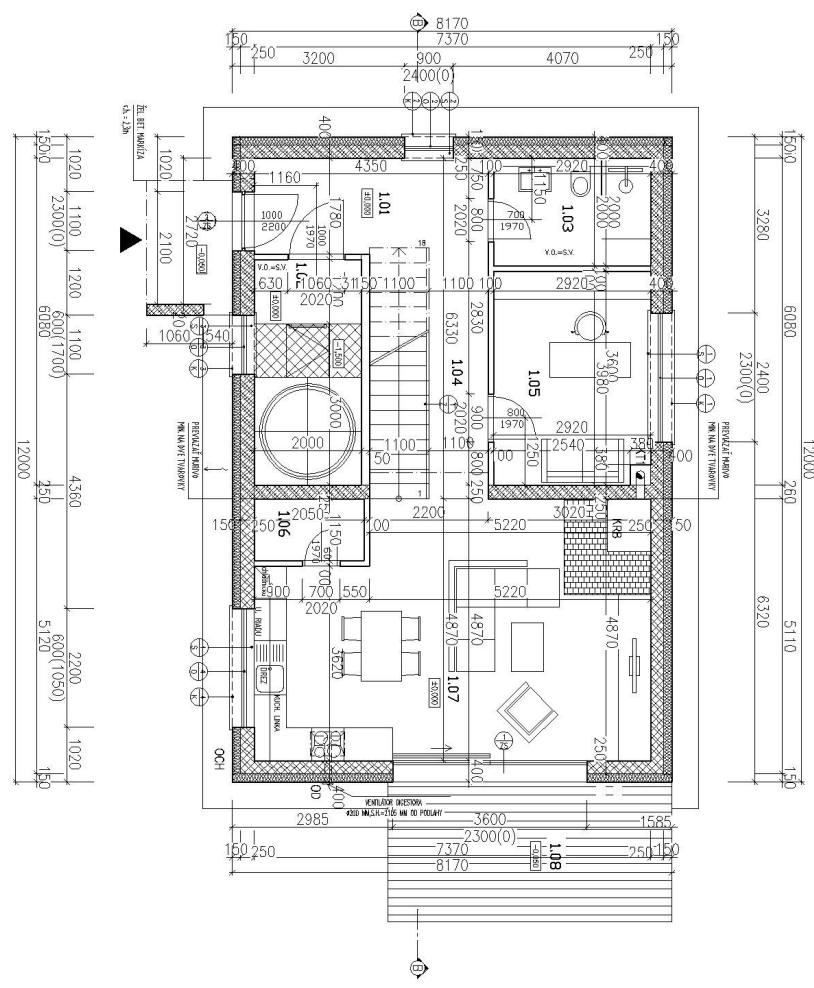

Fig. 2 Ground floor plan of a model house (Source: architects of the building: Peter Beňuška and Peter Topinka) [4]

\section{Thermal - technical properties of building structures and energy balance of a low energy family house}

The heat transfer coefficients of individual building structures are in Table 1.

The designed heat input in accordance with STN EN $12831-1$ is $7.84 \mathrm{~kW}$. The energy demand for heating determined by the degree days method is $Q_{U K}=58.7 \mathrm{GJ} /$ year. The specific heat loss of the enclosed space is $q_{O P}=13.61 \mathrm{~W} / \mathrm{m}^{3}$. Specific heat demand for heating $E_{2}=48.6 \mathrm{kWh} /\left(\mathrm{m}^{2}\right.$ year $)$, i.e. the building is classified as a low energy building.



Fig. 3 The $1^{\text {st }}$ floor plan of a model house (Source: architects of the building: Peter Beňuška and Peter Topinka) [4]

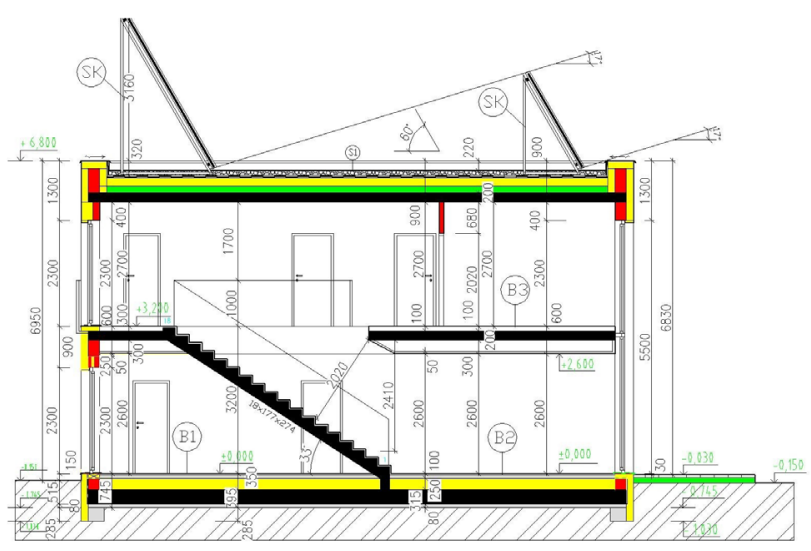

Fig. 4 Cross-section plan of a model house (Source: architects of the building: Peter Beňuška and Peter Topinka) [4]

Table 1 Heat transfer coefficient $U\left(\mathrm{~W} /\left(\mathrm{m}^{2} \mathrm{~K}\right)\right)$

\begin{tabular}{lcc} 
No. & Name of building structure & $U\left(\mathrm{~W} /\left(\mathrm{m}^{2} \mathrm{~K}\right)\right)$ \\
\hline 1 & Perimeter wall & 0.2 \\
2 & Roof & 0.2 \\
3 & Floor & 0.2 \\
4 & Window & 0.8 \\
5 & Entrance door & 1.7 \\
\hline
\end{tabular}


Influence of ATI on the course of isotherms in building structures (perimeter wall of brick masonry $250 \mathrm{~mm}$ thick, insulated by $150 \mathrm{~mm}$ EPS) depending on the mean temperature of the heating medium under the assumption of a steady state is shown in Fig. 5.

Based on the thermal-technical assessment it is clear that the mean temperature in the ATI area has a minimal effect on the increase of the surface temperature on the exterior side of the building structure by only $+0.3{ }^{\circ} \mathrm{C}$, from $-10.74{ }^{\circ} \mathrm{C}$ in the case of a building structure without ATI to $-10.44{ }^{\circ} \mathrm{C}$; at building structure with ATI at medium temperature up to $+50{ }^{\circ} \mathrm{C}$.

We design objects with ATI so that the whole envelope, i.e. the floor, the perimeter walls and the roof form an "energy barrier" of the building, which is also a large-capacity heat/cold storage tank. Due to the higher temperature of the ATI between the static (interior) and insulating



Fig. 5 Course of temperatures (isotherms) in the perimeter wall (Source: Own work of the author, Daniel Kalús) (exterior) part of the envelope building structure, the heat losses are also higher by conduction depending on the mean temperature in the ATI. This increase in heat losses by individual building structures is evident from Table 2, columns $6,7,8$. Heat losses by transparent structures and heat losses by ventilation remain unchanged [5-7].

In terms of the calculation procedure of the designed heat input, there is also the determination of the heat input for heating-up capacity, which takes into account the reduction of the internal temperature of the interior during night or day reduced demand and the subsequent increase of the heat source to achieve the required internal temperature (Table 2, column 10).

For buildings with ATI, due to the long-term accumulation of heat/cold in envelope structures (floor, walls and roof), where the heat source and the entire heating/cooling system is off for several days during the intermittent period, we do not consider determination of projected heat input with heat input for heating-up capacity (Table 2, column 10).

All results of calculation of projected heat input in accordance with STN EN 12831-1 depending on the mean temperature in the ATO in the range from $+22{ }^{\circ} \mathrm{C}$ to $+50{ }^{\circ} \mathrm{C}$ are given in Table 2 .

A very important aspect of building structures with an internal energy source (ATI) is the fact that envelope building structures also become the end-point elements of the heating/cooling energy system - large-area low-temperature heating, respectively, large-area high-temperature cooling (floor, wall, ceiling). Specific heat losses of individual building structures (floor, wall, ceiling) towards the exterior are in Table 3, columns 3, 4, 5. Specific heat outputs for heating of

Table 2 Calculation results of projected heat input

\begin{tabular}{|c|c|c|c|c|c|c|c|c|c|c|}
\hline \multirow[t]{2}{*}{$\begin{array}{l}\text { House } \\
\text { type }\end{array}$} & \multicolumn{3}{|c|}{$\begin{array}{l}\text { Mean temperature between the } \\
\text { static part and the insulation part of } \\
\text { the building construction }\left({ }^{\circ} \mathrm{C}\right)\end{array}$} & \multicolumn{4}{|c|}{ Transmission heat loss through ... (W) } & \multirow{2}{*}{$\begin{array}{c}\text { Ventilation } \\
\text { heat loss }(\mathrm{W}) \\
\text { Roof }\end{array}$} & \multirow{2}{*}{$\begin{array}{l}\text { Heating-up } \\
\text { capacity (W) }\end{array}$} & \multirow{2}{*}{$\begin{array}{l}\text { Design heat } \\
\text { load* (W) } \\
-\end{array}$} \\
\hline & Wall & Floor & Roof & Window & Ground & Roof & Walls & & & \\
\hline $\begin{array}{l}\text { Column } \\
\text { No. }\end{array}$ & 2. & 3. & 4. & 5. & 6. & 7. & 8. & 9. & 10. & 11. \\
\hline $\begin{array}{l}\text { House } \\
\text { without } \\
\text { ATI }\end{array}$ & 17.34 & 19.25 & 18.57 & 1222.00 & 288.00 & 595.20 & 1264.30 & 2357.00 & 2112.00 & 7838.50 \\
\hline \multirow{8}{*}{$\begin{array}{l}\text { House } \\
\text { with } \\
\text { ATI }\end{array}$} & 22.00 & 22.00 & 22.00 & $1,222.00$ & 336.00 & 595.20 & $1,631.36$ & $2,357.00$ & 0.00 & $6,141.56$ \\
\hline & 25.00 & 25.00 & 25.00 & $1,222.00$ & 384.00 & 672.00 & $1,835.28$ & $2,357.00$ & 0.00 & $6,470.28$ \\
\hline & 26.00 & 26.00 & 26.00 & $1,222.00$ & 432.00 & 720.00 & $1,937.24$ & $2,357.00$ & 0.00 & $6,668.24$ \\
\hline & 30.00 & 30.00 & 30.00 & $1,222.00$ & 480.00 & 768.00 & $2,039.20$ & $2,357.00$ & 0.00 & $6,866.20$ \\
\hline & 35.00 & 35.00 & 35.00 & $1,222.00$ & 576.00 & 864.00 & $2,243.12$ & $2,357.00$ & 0.00 & $7,262.12$ \\
\hline & 40.00 & 40.00 & 40.00 & $1,222.00$ & 672.00 & 960.00 & $2,447.04$ & $2,357.00$ & 0.00 & $7,658.04$ \\
\hline & 45.00 & 45.00 & 45.00 & $1,222.00$ & 768.00 & $1,056.00$ & $2,752.92$ & $2,357.00$ & 0.00 & $8,155.92$ \\
\hline & 50.00 & 50.00 & 50.00 & $1,222.00$ & 960.00 & $1,152.00$ & $3,058.80$ & $2,357.00$ & 0.00 & $8,749.80$ \\
\hline
\end{tabular}

* for the internal design temperature $+20^{\circ} \mathrm{C}$ and the external design temperature $-11^{\circ} \mathrm{C}$ 
individual building structures (floor, wall, ceiling) towards the interior are in Table 3, columns 6, 7, 8. In Table 3, columns $9,10,11$ the heating outputs of the individual building structures (floor, wall, ceiling) and the total heat input for heating by means of ATI are in Table 3, column 12.

Based on the analysis of the calculated data, it can be stated that the given object with ATI at the average temperature of the heating medium in ATI of $+26{ }^{\circ} \mathrm{C}$ will cover the total heat losses of the object of $6.7 \mathrm{~kW}$, respectively, will produce heat input for heating of $6.8 \mathrm{~kW}$ (outdoor temperature $-11{ }^{\circ} \mathrm{C}$, indoor temperature $+20{ }^{\circ} \mathrm{C}$ ). The assessed LEH (low-energy house) without ATI has a projected heat input of $7.8 \mathrm{~kW}$ and the same building with application of ATI has a projected heat input of $6.8 \mathrm{~kW}$. This reduction in heat input by $13 \%$ is due to the accumulation of heat in envelope building structures. In addition to lower projected heat input for heating, other factors influence the overall energy intensity [8-11].

One of the most important factors is the operating time of the heat source and the heating/cooling system. Based on measurements taking place since October 2011 at the experimental house in Tomášov city, we assume that the operating time of the heat source and heating system is at least $20 \%$ shorter in applications with ATI than the operating time in applications without ATI. Then the energy need according to the degree day method will be $58.70 \mathrm{GJ} /$ year for the application without ATI and 40.30 GJ/year for the application with ATI [12].
This difference indicates a lower energy intensity of the building with ATI as much as $31.35 \%$ [13-15].

Table 4 (columns 4, 5, 6) [16] shows the percentage efficiency of building structures with ATI (floor, walls and roof). It expresses the ratio of the specific heating power to the total power of ATI, i.e. specific heating output + specific heat loss of the building structure with ATI. Building structures without ATI have this value equal to zero.

\section{Conclusion}

The current state of development of technologies for the use of RES does not allow to the full extent the use of all renewable energy sources. Most of the modern technologies are at a stage introduction to the market, when their investment intensity is still very high. High investment intensity is also related to the fact that these technologies are imported.

For the time being, Active Thermal Insulation is applied either to a building where for the purpose of distributing a low-temperature heat transfer medium obtained from solar and geothermal energy a pipe or hose system is attached to the perimeter wall of a built building and covered with plaster, thermal insulation, and covering plaster. This applies both to new buildings and to thermal insulation of already existing buildings. However, such method of implementing ATI is financially demanding, time consuming, and complicated.

These shortcomings of the existing method of implementing ATI led to the possibility of solving this problem by appropriate technical means. The result of this effort

Table 3 Recapitulation of specific heat losses and specific heat heating outputs and heat inputs for heating of individual building structures (floor, wall, ceiling)

\begin{tabular}{|c|c|c|c|c|c|c|c|c|c|c|c|}
\hline House type & 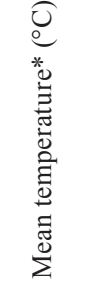 &  & 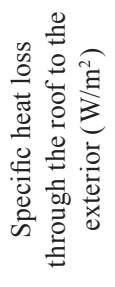 & 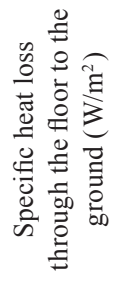 &  & 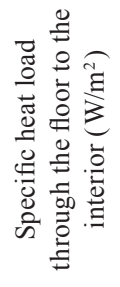 & 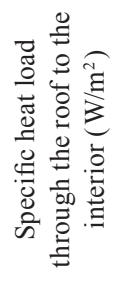 & 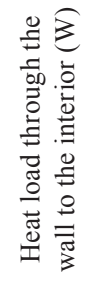 & 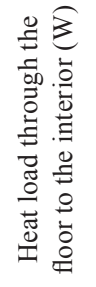 & 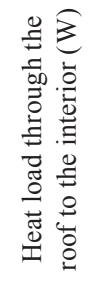 & 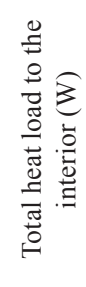 \\
\hline Column No. & 2. & 3. & 4. & 5. & 6. & 7. & 8. & 9. & 10. & 11. & 12. \\
\hline $\begin{array}{l}\text { House without } \\
\text { ATI }\end{array}$ & 17.43 & 6.20 & 6.20 & 3.00 & 0.00 & 0.00 & 0.00 & 0.00 & 0.00 & 0.00 & 0.00 \\
\hline \multirow{8}{*}{$\begin{array}{l}\text { House with } \\
\text { ATI }\end{array}$} & 22.00 & 8.00 & 6.20 & 3.50 & 2.00 & 6.00 & 9.00 & 407.84 & 576.00 & 864.00 & 1,847 \\
\hline & 25.00 & 9.00 & 7.00 & 4.00 & 6.00 & 16.00 & 24.00 & 1,223 & 1,536 & 2,304 & 5,063 \\
\hline & 26.00 & 9.50 & 7.50 & 4.50 & 9.00 & 24.00 & 28.00 & 1,835 & 2,304 & 2,688 & 6,827 \\
\hline & 30.00 & 10.00 & 8.00 & 5.00 & 12.00 & 32.00 & 47.00 & 2,447 & 3,072 & 4,512 & 10,031 \\
\hline & 35.00 & 11.00 & 9.00 & 6.00 & 18.00 & 48.00 & 71.00 & 3,670 & 4,608 & 6,816 & 15,094 \\
\hline & 40.00 & 12.00 & 10.00 & 7.00 & 24.00 & 64.00 & 95.00 & 4,894 & 6,144 & 9,120 & 20,158 \\
\hline & 45.00 & 13.50 & 11.00 & 8.00 & 30.00 & 80.00 & 119.00 & 6,117 & 7,680 & 11,424 & 25,221 \\
\hline & 50.00 & 15.00 & 12.00 & 10.00 & 36.00 & 96.00 & 142.00 & 7,341 & 9,216 & 13,632 & 30,189 \\
\hline
\end{tabular}

\footnotetext{
* between the static part and the insulation part of the building construction - wall
} 
Table 4 Efficiency of building structures with ATI

\begin{tabular}{|c|c|c|c|c|c|c|}
\hline $\begin{array}{l}\text { House } \\
\text { type }\end{array}$ & $\begin{array}{l}\text { Mean temperature } \\
\text { between the static part } \\
\text { and the insulation part of } \\
\text { the building construction }\end{array}$ & $\begin{array}{l}\text { Specific heat loss } \\
\text { of the conditioned } \\
\text { space }\end{array}$ & $\begin{array}{l}\text { Efficiency of the } \\
\text { wall with ATI }\end{array}$ & $\begin{array}{l}\text { Efficiency of the } \\
\text { floor with ATI }\end{array}$ & $\begin{array}{l}\text { Efficiency of the } \\
\text { roof with ATI }\end{array}$ & $\begin{array}{l}\text { Energy demand for } \\
\text { heating calculated by } \\
\text { the degree-day method }\end{array}$ \\
\hline $\begin{array}{l}\text { Column } \\
\text { No. }\end{array}$ & 2. & 3. & 4. & 5. & 6. & 7. \\
\hline $\begin{array}{l}\text { Unit of } \\
\text { measure }\end{array}$ & $\left({ }^{\circ} \mathrm{C}\right)$ & $\left(\mathrm{W} / \mathrm{m}^{3}\right)$ & $(\%)$ & $(\%)$ & $(\%)$ & (GJ/year) \\
\hline $\begin{array}{l}\text { House } \\
\text { without } \\
\text { ATI } \\
\end{array}$ & 17.43 & 13.61 & 0.00 & 0.00 & 0.00 & $\mathbf{5 8 . 7 0}$ \\
\hline \multirow{8}{*}{$\begin{array}{l}\text { House } \\
\text { with } \\
\text { ATI }\end{array}$} & 22.00 & 10.66 & 20.00 & 63.16 & 59.21 & \multirow{8}{*}{40.30} \\
\hline & 25.00 & 11.23 & 40.00 & 80.00 & 77.42 & \\
\hline & 26.00 & 11.58 & 48.65 & 84.21 & 78.87 & \\
\hline & 30.00 & 11.92 & 54.55 & 86.49 & 85.45 & \\
\hline & 35.00 & 12.61 & 62.07 & 88.89 & 88.75 & \\
\hline & 40.00 & 13.30 & 66.67 & 90.14 & 90.48 & \\
\hline & 45.00 & 14.16 & 68.97 & 90.91 & 91.54 & \\
\hline & 50.00 & 15.19 & 70.59 & 90.57 & 92.21 & \\
\hline
\end{tabular}

* in accordance with STN EN 17248 [16]

are variants of structures of thermal insulation panels with active heat transfer control (Active Thermal Insulation ATI) according to the invention described in the European patent document EP 2572057 B1 [17].

Thermal insulation panels with active heat transfer control (Active Thermal Insulation) have a wide field of application. These are not only new constructions, but also reconstructions of buildings. Unification of production is

\section{References}

[1] Chmýrny, I. "Tepelná ochrana budov" (Thermal protection of buildings), Jaga group, Bratislava, Slovakia, 2003. (in Slovakian)

[2] Kurčová, M. "Possibilities of Energy Savings at Replacement Boiler for Gas Fuel into Renewable Energy Source", In: EXPRES 2018: Proceedings of the 10th International Symposium on Exploitation of Renewable Energy Sources and Efficiency, Inženjersko-techničko udruženje vojvođanskih Mađara, Subotica, Serbia, 2018, CD-ROM, pp. 25-28.

[3] Cvíčela, M. "Analýza stenových energetických systémov. Dizertačná práca" (Analysis of wall energy systems), PhD Dissertation, Slovak University of Technology in Bratislava, 2011. (in Slovakian)

[4] Benuska, P., Topinka, P. "Beňuška - Topinka architekti" (Benuska - Topinka architects), [online] Available at: https://www. benuskatopinka.sk/ [Accessed: 06 October 2019] (in Slovakian)

[5] Krajčík, M., Petráš, D., Skalíková, I. "Energetické hodnotenie budov" (Energy rating of buildings), Spektrum STU, Bratislava, Slovakia, 2019. (in Slovakian)

[6] Janík, P. "Optimalizácia energetických systémov s dlhodobou akumuláciou tepla" (Optimization of energy systems with long-term heat accumulation), PhD Thesis, Slovak University of Technology in Bratislava, 2013. (in Slovakian) also supported by the fact that a large part of residential buildings in Slovakia, Central and Eastern Europe are not yet thermally insulated. By elaborating sample - type documents with laying drawings for individual types, especially panel residential buildings, could significantly contribute to mass production of thermal insulation panels with controlled heat transfer [18-22].

[7] Zhu, Q., Xu, X., Gao, J., Xiao, F. "A semi - dynamic model of active pipe-embedded building envelope for thermal performance evaluation", International Journal of Thermal Sciences, 88 , pp. 170-179, 2015. https://doi.org/10.1016/j.ijthermalsci.2014.09.014

[8] Krzaczek, M., Kowalczuk, Z. "Thermal Barrier as a technique of indirect heating and cooling for residential buildings", Energy and Buildings, 43(4), pp. 823-837, 2011.

https://doi.org/10.1016/j.enbuild.2010.12.002

[9] Krecké, E. D. "Terrasol Isomax", [online] Available at: www. isomax-terrasol.eu [Accessed: 20 October 2020]

[10] Zhang, C., Qin, J., Yang, Q., Zhang, S., Bao, W. "Design and heat transfer characteristics analysis of combined active and passive thermal protection system for hydrogen fueled scramjet", International Journal of Hydrogen Energy, 40(1), pp. 675-682, 2015. https://doi.org/10.1016/j.ijhydene.2014.11.036

[11] Kalús, D. "Interiérové tepelne aktívne panely s integrovanou aktívnou plochou, 1. čast" (Interior thermally active panels with integrated active surface, Part 1), [online] Available at: http://www. stavebne-forum.sk/sk/article/18284/ [Accessed: 15 September 2020] (in Slovakian) 
[12] European Parliament and The Council of European Union, "Directive (EU) 2018/844 of the European Parliament and of the Council of 30 May 2018 amending Directive 2010/31/EU on the energy performance of buildings and Directive 2012/27/EU on energy efficiency", Official Journal of the European Union, L 156, pp. 75-91, 2018. [online] Available at: https://eur-lex.europa.eu/eli/ dir/2018/844/oj [Accessed: 07 October 2020]

[13] Sternová, Z. "STN 730540-2 + Z1 + Z2 Tepelná ochrana budov. Tepelnotechnické vlastnosti stavebných konštrukcií a budov. Čast' 2: Funkčné požiadavky. Konsolidované znenie" (Thermal protection of buildings. Thermal performance of buildings and components. Part 2: Functional requirements. Consolidated text), Slovak Office of Standards, Metrology and Testing, Bratislava, Slovakia, 2019. (in Slovakian)

[14] Sternová, Z., Bendžalová, J. "STN EN ISO 13790/NA Energetická hospodárnost' budov. Výpočet potreby energie na vykurovanie a chladenie" (Energy performance of buildings. Calculation of energy use for space heating and cooling), Slovak Office of Standards, Metrology and Testing, Bratislava, Slovakia, 2010. (in Slovakian)

[15] Magyar, J. "STN EN 12831-1 Energetická hospodárnost' budov. Metóda výpočtu projektovaného tepelného príkonu. Čast' 1 : Tepelný príkon, Modul M3-3" (Energy performance of buildings. Method for calculation of the design heat load. Part 1: Space heating load, Module M3-3), Slovak Office of Standards, Metrology and Testing, Bratislava, Slovakia, 2019. (in Slovakian)

[16] Slovak Office of Standards, Metrology and Testing "STN EN 17248 Potrubné systémy dial'kového vykurovania a dial'kového chladenia. Termíny a definície" (District heating and district cooling pipe systems - Terms and definitions), Slovak Office of Standards, Metrology and Testing, Bratislava, Slovakia, 2020. (in Slovakian)
[17] Kalús, D., Páles, P., Pelachová, L., Belešćák \& Partneri, Beleščák, L. "Tepelno-izolačný panel pre systémy s aktívnym riadením prechodu tepla" (Heat insulating panel with active regulation of heat transition), Slovakia, EP 2572057 B1, 2015. (in Slovakian)

[18] Šimko, M., Krajčík, M., Šikula, O., Šimko, P., Kalús, D. "Insulation panels for active control of heat transfer in walls operated as space heating or as a thermal barrier: Numerical simulations and experiments", Energy and Buildings, 158, pp. 135-146, 2018. https://doi.org/10.1016/j.enbuild.2017.10.019

[19] Krajčík, M., Šikula, O. "Heat storage efficiency and effective thermal output: Indicators of thermal response and output of radiant heating and cooling systems", Energy and Buildings, 229, Article number: 110524, 2020.

https://doi.org/10.1016/j.enbuild.2020.110524

[20] Zhou, L., Li, C. "Study on thermal and energy-saving performances of pipe-embedded wall utilizing low-grade energy", Applied Thermal Engineering, 176, Article number: 115477, 2020. https://doi.org/10.1016/j.applthermaleng.2020.115477

[21] Masaryk, M., Mlynár, P. "Solar air-condition by ejector cooling", AIP Conference Proceedings, 2000, Article number: 020013, 2018. https://doi.org/10.1063/1.5049920

[22] Plytaria, M. T., Bellos, E., Tzivanidis, C., Antonopoulos, K. A. "Numerical simulation of a solar cooling system with and without phase change materials in radiant walls of a building", Energy Conversion and Management, 188, pp. 40-53, 2019. https://doi.org/10.1016/j.enconman.2019.03.042 